\title{
MINIREVEW
}

\section{Current status of viral diseases in Indian shrimp aquaculture}

\author{
G. M. TANDEL, K. RIJI JOHN, M. ROSALIND GEORGE, M. J. PRINCE JEYASEELAN
}

Department of Fish Pathology and Health Management, Fisheries College and Research Institute, Thoothukudi 628008, India

Received December 10, 2014; revised August 25, 2016, accepted March 10, 2017

\begin{abstract}
Summary. - The intensification of aquaculture has been unique in showing the overwhelming changes in global food production in the last 100 years. Presently, it is playing a vital role in the economies of several countries. Conversely, it is also to be noted that the progression of aquaculture has been the foundation of anthropogenic alteration of a gigantic hierarchy and hence not astonishingly, it resulted in spread and emergence of an increasing group of new unknown diseases. In India, Penaeus monodon, black tiger shrimp was previously the foremost-cultivated shrimp species. Subsequently in 2008, the American white leg shrimp Litopenaeus vannamei has effectively replaced it. The change in dominant species has affected disease concerns in India as well as in world shrimp aquaculture. White spot syndrome virus (WSSV) is the most deleterious for both species. Hepatopancreatic parvovirus (HPV), Monodon baculovirus (MBV) and Infectious hypodermal and hematopoietic necrosis virus (IHHNV) are the other significant infectious agents of P. monodon and L. vannamei. An emerging disease of loose shell syndrome (LSS) was already reported from India during late 1998. A more recent disease of L. vannamei in India is monodon slow growth syndrome (MSGS), a component of which seems to be Laem-Singh virus (LSNV). Thus, most of the information in this review relates to new emerging pathogens that threaten the cultivation shrimp industry in India.
\end{abstract}

Keywords: White spot syndrome virus; shrimp aquaculture; virus disease; Infectious hypodermal and hematopoietic necrosis virus; Hepatopancreatic parvovirus; Laem-Singh virus; loose shell syndrome

\section{Contents:}

1. Introduction

2. White spot syndrome virus (WSSV)

3. Monodon-type baculovirus (MBV)

4. Infectious hypodermal and hematopoietic necrosis virus (IHHNV)

5. Hepatopancreatic parvovirus (HPV)

6. Laem-Singh virus (LSNV)

E-mail: rijijohn@gmail.com; phone: +91-9443657839.

Abbreviations: FAO $=$ Food and Agriculture Organization; ha $=$ hectare; HPV = Hepatopancreatic parvovirus; IHHNV = Infectious hypodermal and hematopoietic necrosis virus; LSNV = Laem-Singh virus; $\mathrm{LSS}=$ loose shell syndrome; $\mathrm{MBV}=$ Monodontype baculovirus; MSGS = monodon slow growth syndrome; OIE $=$ World Organisation for Animal Health; WSD = white spot disease; WSSV = White spot syndrome virus
7. Loose shell syndrome (LSS)

8. Conclusion

\section{Introduction}

This review presents an overview of current viruses in cultivated shrimps in India. To understand the current situation, it is important to know how Indian shrimp aquaculture has shifted from farming of giant tiger shrimp, P. monodon, to the exotic American white leg shrimp, L. vannamei, since 2008. Availability of quality shrimp seed was the main reason responsible for the shift from tiger shrimpt to L. vannamei. Previously, rearing the post-larvae of wild-captured broodstock was practised in tiger shrimp-dominated farming in India. But larvae were infected with WSSV and broodstock transmitted the WSSV (along with other viruses) to their 
(a)

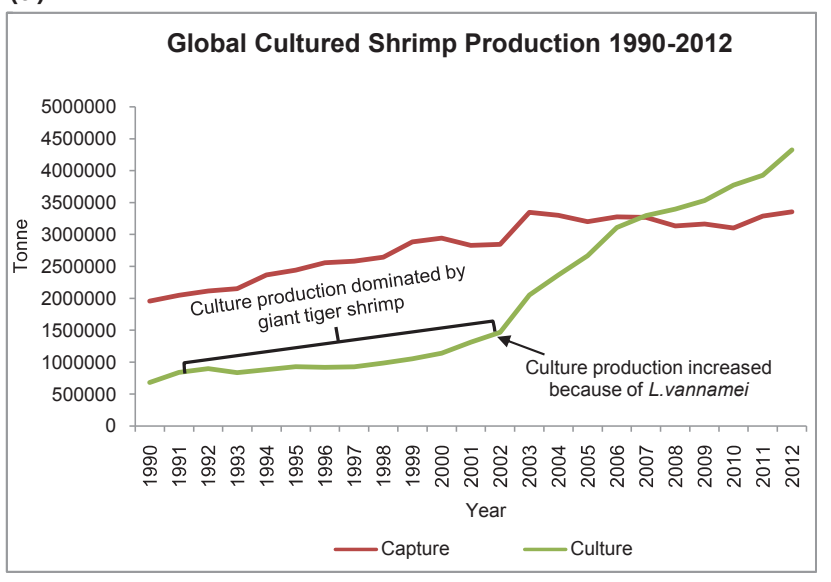

(b)

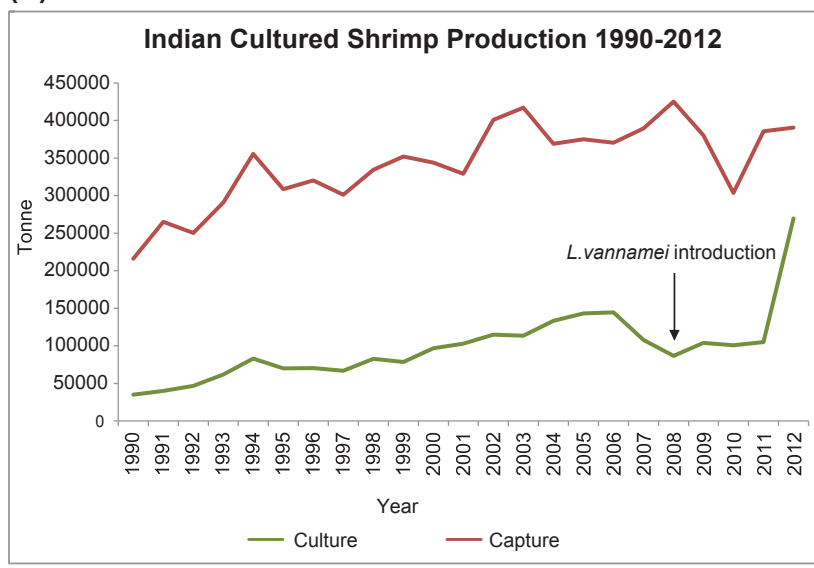

Fig. 1

World and Indian shrimp production

(a) Global shrimp production from capture fisheries and culture fisheries during 1990-2012. Culture fisheries were dominated by P. monodon until 2003 and by L. vannamei afterwards (FAO, 2014). (b) Indian shrimp production from capture fisheries and culture fisheries during 1990-2012. Culture production rose in 2008 after L. vannamei replaced P. monodon (FAO, 2014).

offspring. Thus, the larvae that were used to stock for cultivation became the cause of white spot disease (WSD) outbreak. With the use of genetically improved seeds of L. vannamei, which were specific pathogen free, this problem of WSSV outbreak was controlled. These seeds originated from the Oceanic Institute in Hawaii as a result of cooperative efforts in the US Marine Shrimp Research Program (Moss et al., 2005). These seeds grew healthy in domestic Indian semiintensive shrimp culture system and resulted in the increase in Indian shrimp production that was previously dominated by P. monodon (Fig. 1a,b). In India, the estimated brackish water area suitable for undertaking shrimp cultivation is
Table 1. State-wise potential of brackish water shrimp farming and present level of development

\begin{tabular}{llcc}
\hline Sr. & State & $\begin{array}{c}\text { Estimated brackish } \\
\text { water area (ha) }\end{array}$ & $\begin{array}{c}\text { Area under } \\
\text { cultivation (ha) }\end{array}$ \\
\hline 1 & West Bengal & 405,000 & 34,660 \\
2 & Orissa & 31,600 & 11,000 \\
3 & Andhra Pradesh & 150,000 & 50,000 \\
4 & Tamil Nadu & 56,000 & 2,879 \\
5 & Pondicherry & 800 & 37 \\
6 & Kerala & 65,000 & 14,657 \\
7 & Karnataka & 8,000 & 3,500 \\
8 & Goa & 18,500 & 650 \\
9 & Maharashtra & 80,000 & 716 \\
10 & Gujarat & 376,000 & 884 \\
\hline Total & & $1,190,000$ & 118,983 \\
\hline
\end{tabular}

around 1,191 million ha extended over 10 states and union territories, viz. West Bengal, Orissa, Andhra Pradesh, Tamil Nadu, Pondicherry, Kerala, Karnataka, Goa, Maharashtra and Gujarat. Of this available area, only around 0.12 million ha is utilised for shrimp farming at present (Table 1).

Since July 1994, the Indian shrimp industry was under the grip of diseases, mainly WSD, and these have eliminated most of the farms. Viral diseases are the primary problem in shrimp aquaculture, obstructing both social and economic development of the country. Many countries are compelled to provide estimates of disease impacts because of regular occurrence of diseases. The effects of diseases have been estimated in socioeconomic terms, e.g. losses in production, revenue, employment, venture and purchaser confidence; food scarcities, trade breakdown or closure of business. We have summarised the viral pathogens described in Indian shrimp farming sector in terms of their pathology, genomic characteristics and their prevalence across shrimps and other crustacean hosts (Table 2).

\section{White spot syndrome virus (WSSV)}

White spot virus (WSV) or White spot syndrome virus (WSSV) is the causative agent of WSD (Fig. 2a,b). WSSV is one of the most serious threats in shrimp farming industry in Asia (since 1992) and Latin America (since 1999). WSSV is an extremely virulent pathogen with a large number of host species (Flegel et al. 1997; Lightner and Redman, 1998), having a potential to infect wide host range among decapod crustaceans (e.g., marine shrimps, freshwater prawns, crabs, lobsters, crayfish etc.) (Lo et al., 1996; Flegel, 1997; Flegel and Alday-Sanz, 1998; Leu et al., 2009). Although the susceptibility to the disease varies from species to species, and some of them have been reported to develop very high 
Table 2. Emerging viral pathogens in Indian shrimp aquaculture

\begin{tabular}{|c|c|c|c|c|}
\hline Genome & Family & Pathogen/Pathogen group & Year of reported in India & OIE listed diseases ${ }^{*}$ \\
\hline \multicolumn{5}{|c|}{ DNA Viruses } \\
\hline dsDNA & Nimaviridae & WSSV - genus Whispovirus & 1994 & Yes \\
\hline dsDNA & Baculoviridae & MBV - an occluded enteric Baculovirus & 1993 & No \\
\hline \multirow[t]{2}{*}{ ssDNA } & Parvoviridae & IHHNV - a systemic Parvovirus & 1998 & Yes \\
\hline & & HPV - enteric parvoviruses & 2002 & No \\
\hline \multicolumn{5}{|c|}{ RNA Virus } \\
\hline ssRNA & Barnaviridae & LSNV - Luteovirus-like (unclassified) & 2007 & No \\
\hline
\end{tabular}

Source: Walker et al. (2010) and www.oie.int. ${ }^{\star}$ Listed by OIE as on 2013.

viral loads even in the absence of clinical signs, it is potentially lethal to most of the commercially cultivated penaeid shrimp species (OIE 2003). WSSV is a large double-stranded DNA (dsDNA) rod-shaped to oval virus with a trilaminar envelope of the size ranging between 80-120 x 250-380 nm (Wang et al., 1995; Inouye et al., 1996; Durand et al., 1997; Kanchanaphum et al., 1998; van Hulten et al., 2001). A hypertrophied nucleus of infected cell is the site where virions are generated without the production of occlusion bodies. The first outbreak of the WSD was reported in Fujian Province of China in 1992 (Zhan et al., 1998). Soon after, it was reported in Taiwan and Japan and has since become serious threat throughout shrimp farming regions of Asia and the Americas (Inouye et al., 1994; Chou et al., 1995; Flegel, 1997). In India, according to the existing reports, WSSV was first noticed in 1994 on black tiger shrimp (P. monodon) from Visakhapatnam of Andhra Pradesh state to Sirkali of Tamil Nadu state, covering a very large area (Anonymous, 1994; Shankar and Mohan, 1994). Since 1994, WSSV continues to threaten entire shrimp farming industry in India through the ferocity of infection. However, the prevalence has been now reduced owing to strict biosecurity measures adopted by farmers (John et al., 2010).

Multiple infections of WSSV with MBV and HPV were reported in hatchery-reared post-larvae of $P$. monodon (Manivarnnam et al., 2002; Otta et al., 2003; Umesha et al., 2003). WSSV has been found in P. monodon from Andaman water and also in other crustaceans such as mud crab, Scylla serrata and banana shrimp Fenneropenaeus merguiensis (John et al., 2008; Sethi et al., 2011). WSSV has also been found to infect freshwater crabs with severe infectivity potential, causing complete mortality in experimental infections (Sahulhameed et al., 2001). Several genotypes of WSSV have been noticed in Indian shrimp farms with varying infectivity potential (Waikhom et al., 2006; John et al., 2010). In recent studies, WSSV infection was found in white leg shrimp L. vannamei under semi-intensive culture condition in India (Balakrishnan et al., 2011). Further, WSSV and MBV prevalence have been reported in wild P. monodon
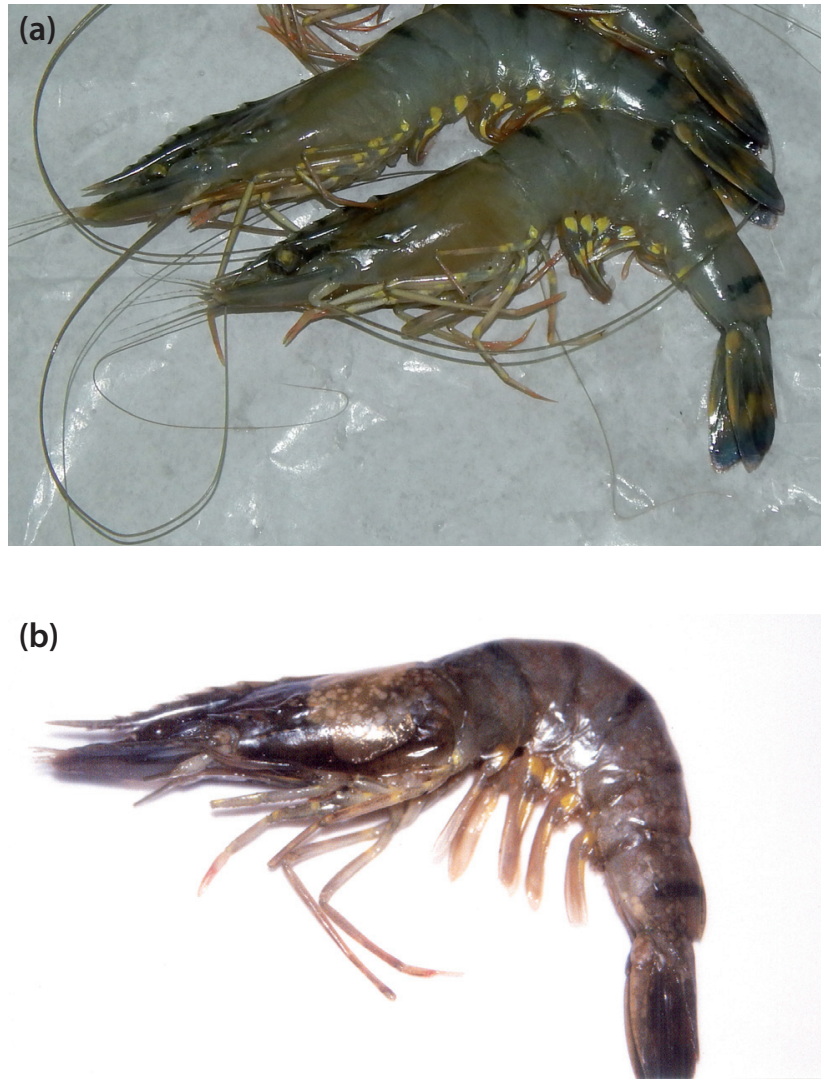

Fig. 2

WSSV infection in tiger shrimp ( $P$. monodon) (a) Normal tiger shrimp; (b) WSSV-infected tiger shrimp (note the white spots on the carapace, broken antennae and pareopods).

broodstock (Remany et al., 2012). WSD is recorded to be the most destructive disease of farmed shrimp with social and economic impacts over last 20 years in India. An estimated annual loss of Rs. 1022.1 crores (US \$ 255 million) have been reported in India due to shrimp diseases during 2006-2008 
(Kalaimani et al., 2013). WSD was listed as the main disease contributing to this heavy loss in shrimp farming.

\section{Monodon-type baculovirus (MBV)}

Monodon-type baculovirus (MBV), also recognized earlier as Penaeus monodon singly enveloped nuclear polyhedrosis virus (PmSNPV), is one of the extensively reported and well-described viruses in shrimp aquaculture. It is a double-stranded DNA virus, rod-shaped, enveloped and studied until recently as type A baculovirus. Size of the virus particles ranges from $265-324 \mathrm{~nm}$ in length and $42-77 \mathrm{~nm}$ in diameter. Nucleic acid of MBV is circular with the genome size ranging from 80 to $160 \mathrm{kbp}$. Yet, complete genome sequence of MBV is not available. MBV has a wide host range including both captured and cultured species of shrimps and also freshwater prawn, Macrobrachium rosenbergii. Existing literature shows that MBV is affecting all life stages of P. monodon with late larval, post larval and young juvenile as the most vulnerable. MBV mainly affects hepatopancreatic tubules and duct epithelium of post larvae, juveniles and adults and the anterior midgut epithelium of very young post larvae. MBV was first identified in Taiwan and subsequently the virus was reported from different parts of the world and from different penaeid shrimps (Liao, 1977; Anderson et al., 1987; Johnson and Lightner, 1988; Lightner, 1988; Lightner et al., 1990, 1992; Lightner and Redman, 1992). In India, high incidence of monodon baculovirus in cultured P. monodon and Penaeus indicus was observed during 1993 to 1995 in two states, Tamil Nadu and Andhra Pradesh. Later, high incidences have been reported from post-larvae of $P$. monodon in Tamil Nadu (Ramasamy et al., 1995; Sundararaj et al., 1996). As mentioned earlier, multiple co-infections of MBV with WSSV and HPV were reported from hatchery-reared post larvae of P. monodon (Manivarnnam et al., 2002; Otta et al., 2003; Umesha et al., 2003). Recent studies show MBV and WSSV presence in wild $P$. monodon broodstock (Remany et al., 2012). Genotypic studies of the MBV isolates have also indicated the existence of strain variation of MBV in Indian shrimps (Suganthi et al., 2012).

\section{Infectious hypodermal and hematopoietic necrosis virus (IHHNV)}

Among the identified penaeid shrimp viruses, Infectious hypodermal and hematopoietic necrosis virus (IHHNV) is the smallest viral pathogen. The virion particle is nonenveloped icosahedron with $22 \mathrm{~nm}$ diameter in size. It is a single-stranded DNA virus with a genome of $4.1 \mathrm{~kb}$ in length. Capsid of this virus contains four polypeptides. The first case of hypodermal and hematopoietic necrosis was reported in Hawaii in 1981, where it had caused mass mortalities in blue shrimp (Penaeus stylirostris) farmed in super-intensive raceways (Lightner et al., 1983). Shortly after, it was discovered in P. stylirostris and L. vannamei in America and Gulf of California (Morales-Covarrubias et al., 1999; Pantoja et al., 1999) and some reports suggest that it might have contributed to the collapse of the capture fishery too. IHHNV has also been identified as the cause of 'runt deformity syndrome' (RDS) in L. vannamei. In 1998, the first conclusive evidence of IHHNV in cultured $P$. monodon was reported in India (Ruby et al., 1998). Later study also reported the presence of IHHNV in India and indicated that this virus could be one of the causes of slow growth in cultured P. monodon (Rai et al., 2009a).

Further, type A IHHNV virus-related sequence was detected in the genome of $P$. monodon from India (Rai et al., 2009b). Recently, IHHNV has been observed in many shrimp samples collected from southeast part of India, mainly Andhra Pradesh and Tamil Nadu. However, IHHNV has not been associated with any serious mortality of shrimps in India.

\section{Hepatopancreatic parvovirus (HPV)}

Hepatopancreatic parvovirus (HPV) or Penaeus monodon densovirus (PmoDNV) was reported from different shrimp species, viz. Penaeus chinensis, F. merguiensis and P. indicus, since early 1980s (Chong and Loh, 1984; Lightner and Redman, 1985; Flegel, 2006). HPV belongs to the family Parvoviridae, characterized by icosahedral symmetry, virion with a size of $22 \mathrm{~nm}$ and a double-stranded DNA genome of $6 \mathrm{~kb}$ (Bonami et al., 1995; Sukhumsirichart et al., 2006; La Fauce et al., 2007). It has been reported that HPV-infected shrimp do not always appear with gross signs of the disease but those, which appear with signs of disease have a tendency to get infected by other pathogens and further it may mask the definite consequence of HPV (Flegel et al., 1992, 1999). HPV occurrence along with WSSV and MBV in hatcheryreared post larvae of $P$. monodon has been already reported in India (Manivarnnam et al., 2002). HPV single infection was found in P. monodon post-larvae (Umesha et al., 2003) and in the wild-caught penaeid shrimps in India (Manjanaik et al., 2005).

\section{Laem-Singh virus (LSNV)}

The monodon slow growth syndrome (MSGS) was first noticed in 2001 in Thailand when shrimp farmers reported an unexplained slow growth of one-month old shrimps (Withyachumnarnkul, 2005). Later, in 2006, Laem-Singh virus (LSNV) was identified as an agent responsible for 
MSGS (Sritunyalucksana et al., 2006). LSNV is a singlestranded RNA (ssRNA) virus (Sritunyalucksana et al., 2006), is unenveloped, icosahedral and has a size of $27 \mathrm{~nm}$ in diameter, similar in size to viruses of the Luteoviridae family (Flegel, 2006). MSGS was reported in Thai shrimp industry as the main reason for causing shift of cultivation from $P$. monodon to L. vannamei. It has been reported that retinopathy is associated with LSNV infection and that it may be linked causally to stunting of $P$. monodon in MSGS ponds (Pratoomthai et al., 2008), but the reason behind retinopathy is not known. However, the presence of a novel integrase-containing element along with LSNV was noticed in the retinal lesions of stunted shrimp from MSGS ponds in Thailand (Panphut et al., 2011). Other possible causes that lead to LSNV-associated stunting of shrimp are still unknown but could be due to other pathogen group or environmental or epigenetic factors. Interestingly, LSNV was detected along with WSSV, HPV and MBV in P. monodon (Prakasha et al., 2007). Though LSNV has been reported from India, it was not always associated with slow growth (Prakasha et al., 2007; Kumar et al., 2011).

\section{Loose shell syndrome (LSS)}

Loose shell syndrome (LSS) was first reported in 1998 among farmed $P$. monodon in India and after that its occurrences have been increasing year after year. Between 1998 and 1999, the incidences of LSS were reported around 23 and $14 \%$, respectively, in shrimp farms near the Vellar estuary in Tamil Nadu during summer and winter crops (Mayavu et al., 2003). The recent study by Marine Products Export Development Authority (MPEDA) and the Network of Aquaculture Centres in Asia-Pacific (NACA) shows LSS incidence of about $27 \%$ at extensive shrimp farms in West Godavari and 5\% in Nellore district of Andhra Pradesh. Another survey conducted by Society of Aquaculture Professionals (SAP) reveals that in 2002 more than $50 \%$ of farms had incidence of LSS. LSS was also reported in Gujarat and Kerala on the West coast of India since 2005. There were several investigations carried out on bacterial and viral pathogens in LSS-affected shrimp in India, but its etiology is still unclear (Loka et al., 2012). Histopathological and bioassay studies carried out on LSS-affected shrimps showed involvement of a filterable infectious virus-like agent associated with the infection (Alavandi et al., 2007, 2008).

\section{Conclusion}

The worldwide development of aquaculture with associated risk of disease incidence and spread would increase globally as the result of rising global population, increasing demand for seafood and decreased supply from capture fisheries. Despite recent development in different facets of the shrimp-farming sector, problems such as emerging diseases still remain and many issues related with biosecurity still persist to be fulfilled. To avoid massive economic loss to the aquaculture sector, definitive precautionary approaches are highly essential. Preventive measures such as development of disease surveillance system and refinement of molecular methods for early detection of carriers should form as an integral part of aquatic biosecurity. In addition, large-scale tangible research in aspects like vaccines, RNAi, probiotics, immunostimulants and other molecular approaches for improved diagnostics are required to combat emerging diseases as a part of health management in aquaculture systems.

\section{References}

Alavandi SV, Babu TD, Abhilash KS, Kalaimani N, Chakravarthy N, Santiago TC, VijayanKK, Glob. Aquac. Advocate10, 80-81, 2007.

Alavandi SV, Babu TD, Abhilash KS, Vijayan KK, Kalaimani N, Santiago TC, Dis. Aquat. Org. 81, 163-171, 2008. https:// doi.org/10.3354/dao01955

Anderson IG, Shariff M, Nash G, Nash M, Asian Fish Sci. 1, 47-64, 1987.

Anonymous, Asian Shrimp News 20, 2-3, 1994.

Balakrishnan G, Peyail S, Kumaran R, Theivasigamani A, Anil SK, Jitesh BS, Srinivasan, Nithya Mary, AACL Bioflux 4, 301-305, 2011.

Bonami JR, Mari J, Poulos BP, Lightner DV, J. Gen. Virol. 76, 813817, 1995. https://doi.org/10.1099/0022-1317-76-4-813

Chong YC, Loh H, Singapore Vet. J. 9, 51-56, 1984.

Chou HY, Huang CY, Wang CH, Chiang HC, Lo CF, Dis. Aquat. Org. 23, 165-173, 1995. https://doi.org/10.3354/ dao023165

Durand S, Lightner DV, Redman RM, Bonami JR, Dis. Aquat. Org. 29, 205-211, 1997. https://doi.org/10.3354/dao029205

Flegel TW, World J. Microbiol. Biotechnol. 13, 433-442, 1997. $\underline{\text { ht- }}$ tps://doi.org/10.1023/A:1018580301578

Flegel TW, Aquaculture 258, 1-33, 2006. https://doi.org/10.1016/j. aquaculture.2006.05.013

Flegel TW, Alday-Sanz V, J. Appl. Ichthyol. 14, 269-273, 1998. https://doi.org/10.1111/j.1439-0426.1998.tb00654.x

Flegel TW, Boonyaratpalin S, Withyachumnarnkul B, In Flegel TW, MacRae IH (Eds): Diseases in Asian Aquaculture III. Fish Health Section, Manila, Asian Fisheries Society, pp. 285-295, 1997.

Flegel TW, Fegan DF, Kongsom S, Vuthikomudomkit S, Sriurairatana S, Boonyaratpalin S, Chantanachookhin C, Vickers JE, MacDonald OD, In Fulks W, Main KL (Eds): Diseases of Cultured Penaeid Shrimp in Asia, the United States. The Oceanic Institute, Honolulu, pp. 74-75, 1992.

Flegel TW, Thamavit V, Pasharawipas T, Alday-Sanz V, Aquaculture 174, 197-206, 1999. https://doi.org/10.1016/S0044-8486(98)00507-9 
Inouye K, Miwa S, Oseko N, Nakano H, Kimura T, Momoyama K, Hiraoka M, Fish Pathol. 29, 149-158, 1994. https://doi. org/10.3147/jsfp.29.149

Inouye K, Yamano K, Ikeda N, Kimura T, Nakano H, Momoyama K, Kobayashi J, Miyajima S, Fish Pathol. 31, 39-45, 1996. https://doi.org/10.3147/jsfp.31.39

John KR, George MR, Iyappan T, Thangarani AJ, Jeyaseelan MJP, J. Fish Dis. 33, 749-758, 2010. https://doi.org/10.1111/ j.1365-2761.2010.01181.x

John KR, George MR, Mansoor MM, Jeyaseelan MJP, In 8th Indian Fisheries Forum, Kolkata, India, 2008.

Johnson PT, Lightner DV, Dis. Aquat. Org. 4, 123-141, 1988. https:// doi.org/10.3354/dao005123

Kalaimani N, Ravisankar T, Chakravarthy N, Raja S, Santiago TC, Ponniah AG, Fish. Technol. 50, 80-86, 2013

Kanchanaphum P, Wongteerasupaya C, Sitidilokratana N, Boonsaeng V, Panyim S, Tassanakajon A, Withyachumnarnkul B, Flegel TW, Dis. Aquat. Org. 34, 1-7, 1998. https://doi. org/10.3354/dao034001

Kumar TS, Krishnan P, Makeshn M, Chaudhari A, Purushothaman CS, Rajendran KV, Dis. Aquat. Org. 96, 21-27, 2011. https://doi.org/10.3354/dao02374

La Fauce KA, Elliman J, Owen SL, Virology 362, 397-403, 2007. https://doi.org/10.1016/j.virol.2006.11.033

Leu JH, Yang F, Zhang X, Xu X, Kou GH, Lo CF, Curr. Top. Microbiol. Immunol. 328, 197-277, 2009. https://doi. org/10.1007/978-3-540-68618-7_6

Liao I, J. Fish Soc. Taiwan 5, 11-29, 1977.

Lightner DV, In Sinderman CJ, Lightner DV (Eds): Disease Diagnosis, Control in North American Marine Aquaculture. Amsterdam : Elsevier 8, 127, 1988.

Lightner DV, Bell TA, Redman RM, Advances in Topical Aquaculture. Tahiti, AQUACOP, IFREMER, Centre de Brest, Plouzane, France, Actes de Colloque. 9, 113-126, 1990.

Lightner DV, Redman RM, Bell TA, Brock JA, J. World Maricult. Soc. 14, 212-225, 1983.

Lightner DV, Redman RM, J. Invert. Pathol. 45, 47-53, 1985. https:// doi.org/10.1016/0022-2011(85)90048-5

Lightner DV, Redman RM, In: Fast AW, Lester LJ (Eds): Culture of Marine Shrimp: Principles, Practices. Amsterdam : Elsevier, pp. 569-588, 1992. https://doi.org/10.1016/ B978-0-444-88606-4.50032-1

Lightner DV, Redman RM, Fish Pathol. 33, 165-180, 1998. https:// doi.org/10.3147/jsfp.33.165

Lo CF, Leu JH, Chen CH,Peng SE, Chen YT, Chou CM,Yeh PY, Huang CJ, Chou HY, Wang CH, Kou GH, Dis. Aquat. Org. 25, 133-141, 1996. https://doi.org/10.3354/dao025133

Loka J, Janakiram P, Geetha GK, Sivaprasad B, Veerendra KM, Ind. J. Fish. 59, 117-123, 2012.

Manivarnnam S, Otta SK, Karunasagar I, Karunasagar I, Dis. Aquat. Org. 48, 233-236, 2002. https://doi.org/10.3354/ dao0 048233

Manjanaik B, Umesha KR, Karunasagar I, Karunasagar I, Dis. Aquat. Org. 28, 255-259, 2005. https://doi.org/10.3354/ dao063255

Mayavu P, Purushothaman A, Kathiresan K, Curr. Sci. 85, 1629$1634,2003$.
Morales-Covarrubias MS, Nunan LM, Lightner DV, Mota-Urbina JC, Garza-Aguirre MC and Chavez-Snachez MC, J. Aquat. Anim. Health.11, 296-301, 1999. https://doi.org/10.1577/ 1548-8667(1999)011<0296:POIHAH>2.0.CO;2

Moss SM, Doyle RW, Lightner DV, Diseases in Asian Aquaculture V. Proc. 5th Symp. Diseases in Asian Aquaculture. Asian Fish. Soc., Manila, pp. 379-393, 2005.

OIE, Office International des Epizooties (OIE), Paris, France, pp. $358,2003$.

Otta SK, Karunasagar I, Karunasagar I, Aquaculture 220, 59-67, 2003. https://doi.org/10.1016/S0044-8486(02) $00340-X$

Pantoja CR, Lightner DV, Holtschmit KH, J. Aquat. Anim. Health 11, 23-34, 1999. https://doi.org/10.1577/1548-8667(1999)011<0023:PAGDOI $>2.0 . \mathrm{CO} ; 2$

Panphut W, Senapin S, Sriurairatana S, Withyachumnarnkul B, Flegel TW, BMC Vet. Res. 7, 18, 2011. https://doi. org/10.1186/1746-6148-7-18

Prakasha BK, Ramakrishna RP, Karunasagar I, Karunasagar I, Dis. Aquat. Org. 77, 83-86, 2007. https://doi.org/10.3354/ $\underline{\text { dao0 } 01835}$

Pratoomthai B, Sakaew W, Sriurairatana S, Wongprasert K, Withyachumnarnkul B, Aquaculture 284, 53-58, 2008. https:// doi.org/10.1016/j.aquaculture.2008.07.040

Rai P, Pradeep B, Karunasagar I, Karunasagar I, Aquaculture 289, 231-235, 2009a. https://doi.org/10.1016/j. aquaculture.2008.12.035

Rai P, Pradeep B, Safeena MP, Karunasagar I, Karunasagar I, Aquaculture, 295, 168-174, 2009b. https://doi.org/10.1016/j. aquaculture.2009.07.015

Ramasamy P, Brennan GP, Jayakumar R, Aquaculture130, 129-135, 1995.

Remany MC, Daly C, Nagaraj S, Panda AK, Jaideep K, Samraj YCT, J. Fish. Dis. 35, 793-798, 2012. https://doi.org/10.1111/ j.1365-2761.2012.01433.x

Ruby R, Sheela B, Muralimanohar A, Sundararaj D, Selvaraj, Chidambaram P, Mohan AC, Vishankar BR, Ind. J. Fish. 45, 183-186, 1998.

Sahulhameed AS, Yoganandhan K, Sathish S, Rasheed M, Murugan V, Kunthala Jayaraman, Aquaculture 201, 179-186, 2001.

Sethi SN, Mahendran V, Nivas K, Krishnan P, Dam Roy S, Ram N, Sethi S, Ind. J. Mar. Sci. 40, 403-406, 2011.

Shankar KM, Mohan CV, Fishing Chimes 14, 23-24, 1994.

Sritunyalucksana K, Apisawetakan S, Boonnat A, Withyachumnarnkul B, Flegel TW, Vir. Res. 118, 31-38, 2006. https:// doi.org/10.1016/j.virusres.2005.11.005

Suganthi G, Uma A, Rebecca G, Saravanabava K, CIB Tech. J. Biotech. 1, 2319-3859, 2012.

Sukhumstrichart W, Attasart P, Boonsangg V, Panyim S, Virology $346,266-277,2006$. https://doi.org/10.1016/j. virol.2005.06.052

Sundararaj A, Murali MB, Sheela PRR, Selvaraj D, Ravishankar B, Ind. J. Fish. 43, 103-105, 1996.

Umesha KR, Uma A, Otta SK, Karunasagar I, Karunasagar I, Dis. Aquat. Org. 57, 141-146, 2003. https://doi.org/10.3354/ $\underline{\text { dao057141 }}$ 
Van Hulten MC, Witteveldt J, Peters S, Kloosterboer N, Tarchini R, Fiers M, Sandbrink H, Lankhorst RK, Vlak JM, Virology 286, 7-22, 2001. https://doi.org/10.1006/ viro.2001.1002

Vijayan KK, Alavandi SV, Rajendran KV, Alagarswami K, Asian Fish Sci. 8, 267-272, 1995.

Waikhom G, John KR, George MR, Jeyaseelan MJP, Aquaculture 261, 54-63, 2006. https://doi.org/10.1016/j. aquaculture.2006.07.031

Walker PJ, Winton JR, Vet. Res. 41, 51, 2010. https://doi. org/10.1051/vetres/2010022
Withyachumnarnkul B, Aquac Asia Pac Mag, 1, 14-15, 2005.

Wang CH, Lo CF, Leu JH, Chou CM, Yeh PY, Chou HY, Tung MC, Chang CF, Su MS, Kou GH, Dis. Aquat. Org. 23, 239-242, 1995. https://doi.org/10.3354/dao023239

Zhan WB, Wang YH, Fryer JL, Yu KK, Fukuda H, Meng QX, J. Aquat. Anim. Health 10, 405-410, 1998. https://doi. org/10.1577/1548-8667(1998)010<0405:WSSVIO >2.0. $\mathrm{CO} ; 2$

Web references: http://www.fao.org/fishery/en; http://www.oie. $\mathrm{int} /$ international-standard-setting/aquatic-manual/ access-online/ 